\title{
DOSSIÊ - APRESENTAÇÃO
}

\section{PANDEMIA \& SOBREVIVÊNCIA - LEITURAS PARA TEMPOS DIFÍCEIS}

\author{
Ana Archangelo \\ Alexandro Henrique Paixão \\ Organizadores ${ }^{1}$
}

“... o real não está na saída nem na chegada: ele se dispõe para a gente é no meio da travessia."

Iniciamos com essas palavras de João Guimarães Rosa, em Grande Sertão: Veredas, porque acreditamos que o que preparamos para este dossiê da revista Linha Mestra, acerca da pandemia Covid-19 e da necessidade de sobrevivência, é um esforço de alguns professores, pesquisadores e psicoterapeutas em atravessar esses tempos tão difíceis e perigosos, reconhecendo que estamos no meio de um novo processo psíquico e social. Neste momento de crise estrutural e sanitária em razão da contaminação mundial pelo vírus "Sars-CoV-2", necessitamos nos preservar em pensamento, buscando compreender uma realidade pouco tangível. Não temos uma única resposta possível, mas análises, fragmentos, ensaios, perguntas e inquietações sobre esse tema. Esperamos, com as Leituras para tempos difíceis, oferecer ao leitor alguma provisão psíquica e epistemológica "sob a pele" exposta das nossas palavras, sensibilizadas por conta do sofrimento mundial dos últimos seis meses.

Com seus milhares de mortos ao redor do globo e consequências gravíssimas para a vida cotidiana, pública e comercial de todas as nações, o coronavírus vem nos desafiando a pensar e a agir em todas as frentes para tentar conter seu avanço trágico. Diante disso, organizamo-nos como profissionais e pesquisadores da educação e da saúde (física e mental) para iniciar uma jornada através de sete artigos que são modos de ler e interpretar fragmentos deste novo fenômeno com características cada vez mais endêmicas e produtor de uma cultura com essas mesmas feições.

Neste dossiê, dispomo-nos a refletir e debater duas categorias sociológicas que alcançaram centralidade nestes últimos meses: educação e cultura. Na verdade, essas categorias funcionarão como eixos articuladores das leituras que nos propomos a realizar sobre o tema da Pandemia e Sobrevivência, apoiadas em perspectivas múltiplas e advindas da psicanálise, da sociologia, da pedagogia, da filosofia e da medicina.

Dentro do eixo da cultura, refletiremos sobre o problema da sobrevivência, propriamente dita, e sobre outras questões relacionadas à intimidade necessária no ambiente doméstico e à questão de gênero dentro de uma nova "estrutura de sentimento" com características endêmicas, algo que tanto alterou decisivamente a nossa imaginação e disposição interpessoal e intrapsíquica quanto intensificou a divisão social do trabalho em casa e no emprego, sobretudo, das mulheres.

Já com o eixo da educação, debateremos mais particularmente seu caráter remoto, adotado por conta do fechamento das escolas e das universidades dentro e fora do Brasil, e olharemos, especialmente, o impacto do ensino a distância na vida dos estudantes e professores.

Educação remota emergencial, gênero, intimidade, relações interpessoais e intrapsíquicas, são diferentes assuntos envolvendo a discussão da Pandemia e Sobrevivência. Neste momento somos todos sobreviventes em uma cultura endêmica e sem muitas chances de mudança. Logo, o que cabe, imperativamente, é sobreviver. Mas, se a ordem das coisas não se alterou ainda, ao menos podemos pensar em reparação, o que implica ser capaz de colocar-nos no lugar de outras pessoas, de identificar-nos com elas e ajudá-las a refletir sobre

\footnotetext{
${ }^{1}$ Nossos agradecimentos a Leda Maria Farah e Leandro Thomaz de Almeida, pela revisão, e a Yasmin Camardelli, pela tradução do artigo de Michael O’Loughlin.
} 
seus medos e dificuldades, como dizia Melanie Klein. Portanto, nosso processo de reparação converte-se em comunicação por meio de diferentes artigos que aqui contam experiências de sobrevivência nesses tempos difíceis de pandemia.

E nossa "travessia" inicia-se pelo eixo da cultura, com um artigo de autoria de Ana Archangelo, intitulado "Sobrevivência em tempos de pandemia ou de como seguir viagem", que é um compêndio reparador de como podemos iniciar e continuar nossa jornada em busca da sobrevivência psíquica em dias que ficamos soterrados pelos medos e pelas dificuldades de tempos difíceis como os atuais.

Tempos demasiado difíceis, conforme anuncia o segundo artigo deste dossiê, de autoria de Alexandro Henrique Paixão, que se pergunta se "Há uma felicidade para os tempos difíceis"(?). Questiona também se cabe deixar os desejos e as paixões nos guiarem num momento em que o imperativo é ficar em casa e não sair à rua, algo que tem intensificado decisivamente a vida mental das famílias.

Famílias que têm presença, através das mulheres, no terceiro artigo, de autoria de Mariana Chaguri e Bárbara Castro, intitulado "Gênero, tempos de trabalho e pandemia: por uma política científica feminista". As autoras refletem sobre a intensificação do trabalho intelectual das mulheres em casa e na universidade, por conta do isolamento social, e colocam as questões de gênero no centro do debate sobre uma nova cultura endêmica.

Alik Wunder cumpre a travessia dentro do eixo cultura com o quarto artigo, intitulado "Prezado Viajante Covid-19" e completa nossa primeira jornada em nome da sobrevivência em tempos de pandemia, convocando-nos a guardar na memória as aprendizagens desta "insólita viagem".

E sobre as formas de aprendizagens, agora sob o eixo da educação, refletem Sabrina Spagnollo Rossetti, Lilian Cardoso de Mendonça, Rosiane Cristina dos Santos Silva e Ana Archangelo, no quinto artigo, intitulado “A educação na pandemia: sobreviveremos?". O texto testemunha a experiência de três professoras da rede pública e uma professora universitária a respeito de como a escola está sobrevivendo em tempos de pandemia e educação remota.

Michael O'Loughlin discorre no sexto artigo sobre a "Preparação para um retorno à escola após a COVID-19: Criar espaços emocionalmente curativos para crianças nas escolas brasileiras" e convida-nos a pensar como será a volta das crianças às escolas no Brasil, quais os efeitos emocionais e os impactos causados na sua aprendizagem e como os professores irão enfrentar esses desafios quando tudo isso acabar. Retornar significará que famílias e crianças terão conseguido sobreviver e poderão sonhar em voltar ao convívio escolar, embora isso possa não ser simples e fácil e demande criar espaços emocionalmente curativos para todas elas.

Eliana Amaral e Soely Polydoro encerram o nosso dossiê com o artigo intitulado "Os desafios da mudança para o Ensino Remoto Emergencial na Graduação na Unicamp - Brasil”. As autoras compartilham conosco experiências decisivas da Unicamp neste processo de isolamento social e nos instigam a refletir sobre os desafios do ensino remoto emergencial nos diferentes espaços da Graduação no ensino superior.

Esta pandemia representa uma longa travessia, e ainda carecemos de abarcar suas causas e consequências nefastas e refletir sobre elas dentro desse "irremediável extenso da vida", conforme professou João Guimarães Rosa. Começamos e encerramos esta apresentação com este querido autor, porque suas palavras sempre nos consolam e nos ajudam a enfrentar aquilo que ele insistentemente repete em várias de suas páginas do seu romance: "viver é muito perigoso...". Reconhecemos e sentimos isso mais do que nunca. Parece, na verdade, que sempre estivemos em perigo, só não sabíamos que estávamos vivendo perigosamente, mas, sobretudo, sobrevivendo. Sobreviver é diferente de viver. E essa diferença ainda é uma novidade que muitos de nós precisamos aprender. 